\title{
1917: The Evolution of Russian Émigré Views of the Revolution
}

Catherine Andreyev (University of Oxford)

7 he place of revolution in Russia and within Russian social thought was greater moderation had been met with almost universal condemnation. ${ }^{2}$ After 1917, the exiled members of the intelligentsia had experienced revolution and had thus modified some of their views. Some sought short-term political responses to the consequences of the revolution, whereas others wanted to produce a more complete and wide-ranging system of ideas. When examining the responses of Russian émigrés to the Russian Revolution and civil war, a variety of approaches can be discerned. First, the main protagonists of 1917 tended to focus on the events of that year and often sought to justify their own actions, as well as criticize the actions of their opponents. ${ }^{3}$ Secondly, new groups arose, which did not find arguments about the course of events in 1917 at all constructive, and wanted to add new elements to the discussion. These groups looked for a political solution to overthrow the Bolsheviks and change

1 Vekhi: Sbornik statei o russkoi intelligentsii (Moscow: I. N. Kushnerev, 1909).

2 See, for example, Pavel Miliukov, "Intelligentsiia i istoricheskaia traditsiia," Intelligentsiia $v$ Rossii: Sbornik statei (St. Petersburg: Zemlia, 1910), 89-192. For a discussion of the debate and reactions to it, see Leonard Schapiro, "The Vekhi group and the Mystique of Revolution," in Leonard Schapiro, Russian Studies (New York: Viking, 1986), 68-92; and Christopher Read, Religion, Revolution and the Russian Intelligentsia 1900-1912 (London: Macmillan, 1979). The introduction to Marshall S. Shatz and Judith E. Zimmerman (eds), Signposts: A Collection of Articles on the Russian Intelligentsia (Irvine, CA: C. Schlacks, Jr., 1986) contains a detailed bibliography.

3 David Anin's Revoliutsiia 1917 goda glazami ee rukovoditelei (Rome: Aurora, 1971) provides a useful shortcut to examples of the differing points of view of various participants in the Revolution. Pavel N. Miliukov's Istoriia vtoroi russkoi revoliutsii (Sofia: Rossiisko-bolgarskoe knigoizdatel'stvo, 1921-23) and Vospominaniia (1859-1917) (New York: Izdatel'stvo imeni Chekhova, 1955) are an example of the way in which a leading politician and historian interpreted events. 
the situation in the USSR. ${ }^{4}$ Others, however, wanted to reconsider what had happened in 1917 and to view the Bolshevik seizure of power from a broader perspective. They hoped this might lead to, firstly, a new understanding of the processes involved in the revolution, and also, perhaps, a changed philosophical outlook. ${ }^{5}$ Despite all the problems encountered by refugees in Europe after the First World War, those members of the Russian intelligentsia who found themselves abroad had the freedom to put forward and discuss a very wide range of views - a freedom which was denied to their compatriots within the USSR.

The majority thought that they would preserve traditional Russian culture and values until their return home, but the longer they stayed abroad, despite their best intentions, the more they became affected by the countries and societies in which they found themselves. Nevertheless, the majority were still focused on Russia, and in their discussions Russia played the major role. In such discussions they continued to address the questions raised in the nineteenth century by Slavophiles and westernizers: How should Russia and Russian culture be defined? How should Russia develop? What should be the response of the intelligentsia? After 1917, an additional question was added into the discussion: How should 1917 and the aftermath of the civil war be understood?

It is no coincidence that scholars refer to Russian political and social thought, rather than the rarer instances of Russian philosophy. Much of the intelligentsia was responding to particular political problems, rather than developing a new philosophical approach. James Scanlan brings Russian thought and philosophy together in one book ${ }^{6}$ and emphasizes the way in which ideas developed by émigrés were received in Russia. In A History of Russian Thought, edited by William Leatherbarrow and Derek Offord, however, there is almost no recognition of developments in emigration. Even the development of Russian theology is only discussed with reference to the Silver Age before 1917. In this volume, Galin Tikhanov, in his very interesting essay on "Continuities in the Soviet Period" discusses the evolution of Marxist thought within the Soviet Union. However, he states that he decided not

4 Krest'ianskaia Rossiia and Miliukov's "new tactic" are an example of this kind of approach (see the discussion below).

5 Both the Eurasianists in Iskhod k Vostoku (Sofia: Rossiisko-bolgarskoe knigoizdatel'stvo, 1921) and Smena vekh (Prague: Nasha rech', 1921) were attempts to rethink the situation within Russia and produce a new approach to the problem in different ways.

6 James P. Scanlan (ed.), Russian Thought after Communism: The Recovery of a Philosophical Heritage (Armonk, NY: M. E. Sharpe, 1994). 
to include a separate overview of émigré currents of thought, because this would have reproduced the wrong notion of Russian émigré intellectuals as being the only heirs of the pre-1917 tradition, thus reinforcing the long-maintained — and rather misleading — picture of a constant and unbridgeable chasm between Soviet and émigré intellectual life. ${ }^{7}$

I agree with Tikhanov that it would be incorrect to maintain that all vestiges of Russian intellectual tradition were destroyed within Russia after 1917-although in many areas it was very difficult for Soviet scholars to maintain, let alone develop, such ideas and traditions. That said, I disagree with the notion that there was an unbridgeable gulf between Soviet and émigré intellectual life, because it can be argued that the greater part of the work of Russian émigré intellectuals was undertaken for Russia's sake and with Russia in mind. Ivan Il'in may have stated this more forcefully than many of his compatriots: "If Russia needs my books, the Lord will save them from destruction; if neither God nor Russia needs them, then I myself don't need them. For I live only for Russia." 8 This sentiment was echoed by many, including those who parted with Il'in on most other issues. P. N. Savitskii, for example, felt that his arrest, imprisonment, and exile in in the USSR in 1945-1957 enabled him to see the real Russia and meet the real Russian people. ${ }^{9}$ Here, perhaps, one can see the continuing ambivalence that the Russian intelligentsia had with the idea of the narod.

Once Russians found themselves abroad, the process of trying to understand what had happened in Russia in 1917 began. Events had moved very quickly and processes which had occurred almost simultaneously were not obvious even to those who played a major role in 1917. The main protagonists began to produce accounts which both justified the actions they had taken in 1917 and clarify the course of events. Archives within the Soviet Union were not available to historians in emigration who began to compile records and memoirs. The journal Arkhiv Russkoi Revoliutsii, produced by Iosif Gessen in

7 Galin Tikhanov, "Continuities in the Soviet Period," in A History of Russian Thought, ed. W. Leatherbarrow and D. Offord (Cambridge: Cambridge University Press, 2010), 311.

8 Quoted in Scanlan, Russian Thought after Communism, 151, from Ivan Il'in's Rodina, russkaia filosofiia, pravoslavnaia kul'tura, compiled with an introduction by E. S. Troitskii (Moscow: n.p., 1992), 3.

9 Letter of P. N. Savitskii to N. E. Andreyev, September 28/29, 1957, in N. E. Andreyev's archive, held in Oxford by C. Andreyev. See Catherine Andreyev, "Arkhiv N. E. Andreeva: Pis'ma P. N. Savitskogo 1957-1966 i stikhi Vostokova." In the press for Slepukhinskie chteniia (2016), due to be published in St. Petersburg in 2018. 
Berlin, and the archive collections in Prague are just some of the more widely known examples of the way in which émigrés felt that they could contribute to a more complete understanding of 1917.

As it became progressively more difficult for historians in the Soviet Union to produce analyses that diverged from the party line, collecting documents and clarifying the facts became increasingly important. The émigré community held that a "future Russia" would need to have access to the truth. Among protagonists of 1917, there were both recriminations and justifications of their own practices and positions.

Menshevik émigrés were very consistent in their criticism of Bolshevik policy. They continued to reiterate that the dictatorial nature of the Bolshevik takeover of power was due to the fact that the revolution had taken place before the Russian working class was large enough or had developed adequate political consciousness. ${ }^{10}$ Many émigrés from the whole spectrum of opinion blamed Alexander Kerensky for his role and decisions, and Kerenshchina in some circles became synonymous with a lack of decisiveness and vacillation. ${ }^{11}$ Much later, George Katkov found discussing 1917 with Kerensky highly irritating, as the acknowledgements to his discussion of the Kornilov affair demonstrate. Katkov wrote:

The most difficult task for me is to express my gratitude to the other main protagonist of this drama, A. F. Kerensky. I knew him only after emigration and had a number of disagreements with him which I would rather forget ... I discussed with him more than once very touchy points relating to the Kornilov affair. On these occasions I found him very much on his guard and evasive in his statements. ${ }^{12}$

Some people blame Kerensky for the disappearance from the Russian archive at Columbia University of key documents relating to the Kornilov affair.

Collecting information and verifying facts might be absorbing for historians, but it was a rather slow business. The émigrés wanted information about what was happening and were eager to find a way to influence the current situation. Pavel Miliukov's new tactic in 1920 consisted of a reappraisal of the

10 Sotsialisticheskii vestnik, published in emigration, first in Berlin, Paris (1921-40) and later in New York (1940-63), was seen as a Menshevik journal in which such views were expressed.

11 Richard Abraham's Alexander Kerensky: First Love of the Revolution (New York: Columbia University Press, 1987) discusses reactions of émigrés towards Kerensky, 351-358.

12 George Katkov, The Kornilov Affair (London: Longman, 1980), viii. 
situation which split his party, the Kadets, and confronted the emigration with a range of contentious issues. Miliukov's views "represented a startling switch from his position of 1917-1918." ${ }^{13}$ He abandoned his support for the monarchy and for the idea of a united Russian Empire. He argued that instead of armed intervention from abroad, émigrés should try to encourage the growth of an anti-Bolshevik popular movement within Russia. This should include a program which would appeal to the people. He stressed the need for the following: republican government; peasant ownership of land; a genuinely federal structure for the Russian state; and an end to arbitrary government and rule from above.

Miliukov's opinion as to why the Bolsheviks had succeeded and the Whites failed offended many of his fellow émigrés. Furthermore, his criticism of the White movement was particularly keenly felt. The idea of new tactics, however, drew people's attention to the need to consider practical measures that might influence the situation within their homeland. The idea, nursed by so much of the military, that a successful campaign would win over the Russian population, was called into question. It should be noted, however, that although the idea of a military campaign to liberate Russia was seen increasingly as unrealistic, the Soviet authorities did not seem to have ruled out this possibility. The 1930 kidnapping of General Kutepov-the head of the veteran association, ROVS, by the OGPU - and also, perhaps, the kidnapping of General Miller in 1937 were partly dictated by the Soviet belief that the émigré Russian military was still a threat. The 1920s saw a great deal of discussion amongst émigré groups as to the best way to influence the Russian population and put pressure on the Soviet government. This was linked with the hope that the USSR might be evolving in ways that would make it easier for them to return home.

Krestianskaia Rossiia is an interesting example of an émigré group which arose after 1917 and wanted to influence the Soviet population in new ways. The members of this party came from the more moderate wing of the Socialist Revolutionary Party. Krestianskaia Rossiia was formed in 1921, but although accepting many aspects of a socialist analysis, it did not agree that the only relationship between classes had to be one of conflict. The party considered that the growth of political consciousness among the peasantry had created a sense of unity and purpose, but that the efforts of the peasantry to become a political force did not mean that the interests of the country as a whole should be

13 Melissa K. Stockdale, Paul Miliukov and the Quest for a Liberal Russia (Ithaca, NY, and London: Cornell University Press, 1996), 282. 
ignored. Krestianskaia Rossiia also stressed the concern for the welfare of the individual (общезначимое благо человеческой кичности), but in order to do so the importance of labor in all spheres of life had to be affirmed and the main areas of human life and culture needed to be democratized.

This group was attempting to counter what it saw as the main weaknesses of Marxism, and most of their ideas had links with both socialist and liberal thinking. The émigré section of Krestianskaia Rossiia continued to send illegal literature to the Soviet Union via contacts in the border areas until collectivization broke these links. ${ }^{14}$ Solzhenitsyn suggested that Stalin had considered having a show trial of members of the Trudovaia Krestianskaia Partiia, but decided that this would have highlighted the discrepancy between Soviet policy and the desires of the peasantry. ${ }^{15}$

Although the focus of discussions was Russia, the emigration could not fail to be affected by the situation in which it found itself. Europe in the 1920s was dealing with the crisis produced by the First World War. Liberal democracy was seen to be struggling with the challenges of the political, social, and economic reconstruction of Europe. This was one of the fundamental reasons for the attraction of fascism, which promised firm leadership and national unity. This coincided with the rise of a younger generation in the émigré community - a generation which felt that the bickering of their elders about who had done what in 1917 was not a constructive approach to the current problems in Russia. They also thought that the senior generation was simply repeating the political divisions and political mistakes of the old order. To some extent, they could be blamed for what had happened. Thus, elements of intergenerational conflict entered the discussion.

John Stephan's magisterial study of Russian fascism ${ }^{16}$ shows the extent that wishful thinking, combined with bravura and ignorance, produced a Russian fascist party. Nevertheless, the Russian Fascist Party (RFP) had few members and was dependent on the enemies of the USSR, Germany and Japan, for its operations. In the end, those states closed it down.

Possibly the most bizarre of the post-revolutionary political movements, which also reflected some of the ideas that produced Russian fascism, was the

14 Vasilii Butenko, “Partiinaia zhizn'. (Itogi 1930-31 goda)," Vestnik Krest'ianskoi Rossii (JuneJuly 1931), 11-15.

15 Aleksandr I. Solzhenitsyn, Arkhipelag GULag, 1918-1956, vol. 1-2 (Paris: YMCA-Press, 1973), 61-2.

16 John J. Stephan, The Russian Fascists: Tragedy and Farce in Exile 1925-1945 (London: Hamish Hamilton, 1978). 
Mladorossy or Young Russians, led by Alexander Kazem-Bek (1902-1977). Their slogan was Tsar' $i$ Sovety (The Tsar and the Soviets). They professed to support the Grand Duke Kirill Vladimirovich, who had been the first member of the imperial family to accept the Provisional Government in 1917 and had marched his men, with red cockades in their hats, through the streets of Petrograd. ${ }^{17}$ The Mladorossy argued that only a monarchical government could lead to greater national awareness and achievement.

The Natsional'no-trudovoi Soiuz was the most long-lasting of the émigré groups which emerged in the prewar period. Their early history is still contentious, ${ }^{18}$ but the official beginning of the organization was at a conference of various Russian youth groups in 1930. The NTS was attracted to the idea of national unity, as put forward by some forms of fascism. However, their emphasis on religious morality set them apart from fascism, and it might be more accurate to say that they had sympathies for forms of authoritarianism. Once the leadership of the movement encountered Nazism, it was clear that the racist elements of Nazism (particularly its characterization of Slavs as Untermenschen) made it impossible for them to seek any form of alliance with the German party.

During the Second World War, the NTS made use of all available opportunities to meet their Soviet compatriots within the occupied territories of the USSR. They also tried to develop the idea of solidarism as a counter to class conflict-but this never developed as a philosophical system. After the Second World War, the NTS was involved in aspects of the Cold War, ${ }^{19}$ but, arguably, was more influential as an émigré publisher. Following the fall of Communism, the organization returned to Russia. Although their journal Posev is still published, it is largely a vehicle for historical accounts and documents, and does not provide commentary on current events.

Eurasianism is viewed as being one of the most far-reaching attempts to redefine Russia's place within the rest of the world, to cast new light on the revolution, and to provide a new philosophy and synthesis for cultural discussion. It has attracted much scholarly interest, ${ }^{20}$ both in its émigré manifestation and

17 George Katkov, Russia 1917: The February Revolution (London: Longman, 1967), 399.

18 See discussion in Catherine Andreyev, Vlasov and the Russian Liberation Movement: Soviet Reality and Émigré Theories (Cambridge: Cambridge University Press, 1986), 183-193.

19 For more, see Benjamin Tromly, “The Making of a Myth," Journal of Cold War Studies 18, no. 1 (2016), 80-111.

20 See Marlène Laruelle, Russian Eurasianism: An Ideology of Empire, trans. M. Gabowitsch (Baltimore, MD: Johns Hopkins University Press, 2008); and Mark Bassin, Sergei Glebov, and Marlène Laruelle (eds), Between Europe and Asia: The Origin, Theories and Legacies of Russian Eurasianism (Pittsburgh: University of Pittsburgh Press, 2015). 
in the way in which some of its ideas have been interpreted in contemporary Russia. Petr Savitskii and Nikolai Trubetskoy began to consider and develop some of their ideas before 1917, but the birth of Eurasianism came with the publication of a volume of essays Iskhod $k$ Vostoku in 1921. Although the ideas have links to previous Russian social and political thought, the aim was to redefine Russia's position in the world as a part of Eurasia. Such a definition involved the discussion of many subjects which had contributed to the creation of Russian culture, including history, geography, economics, linguistics, and ethnography. But it also included the experience of the revolution and civil war. As Savitskii argues, "The Russian Revolution is not an episode of European history only." 21 The Eurasianists posited that the Bolsheviks could be seen as the most extreme example of Western culture. The revolution was not so much an example of class struggle as a rising up of the Russian masses against the domination of a Europeanized elite which had introduced a culture incomprehensible to the people.

This meant that Russia had to define herself correctly. The search for a deeper understanding of Russian culture was a large part of the program, and attracted scholars such as N. P. Toll and G. V. Vernadsky at various points. Another strand of the movement was more political, and resulted from the fact that the movement developed among émigrés. Sergey Glebov argues that it was

the product of the imperial situation ... it is not a history of Russian nationalism or modernism, of geopolitics or structuralism, but all of these contexts that came to shape the movement in various, often contradictory ways. ${ }^{22}$

The support for an ideocratic state was controversial and led to splits within the movement, particularly after 1928. This developed into the third part of the program. The revolution had a positive side and brought about a deeper search for truth and meaning. The intelligentsia had to see the error of their ways and repent. This idea led to a religious worldview, as exemplified in Russian Orthodoxy. The demand to examine all areas of Russian culture was at variance with the unquestioning acceptance of Russian Orthodoxy, and the Eurasianists never managed to find a way to reconcile the different strands of thought within the movement.

21 Petr Savitskii, "Povorot k vostoku," Iskhod k Vostoku 2 (1921), 2.

22 Sergey Glebov, From Empire to Eurasia: Politics, Scholarship and Ideology in Russian Eurasianism (1920s-1930s) (DeKalb, IL: Northern Illinois University Press, 2017), 13. 
Savitskii was always anxious to keep in contact with his Soviet compatriots. In 1927, he became involved in the Trest operation, ${ }^{23}$ and entered Russia illegally. He returned to Prague afterwards, and seems to have thought that he had outwitted the OGPU. He was not arrested, but it is more than likely that the authorities knew about his journey. As stated above, he thought that through his arrest and imprisonment in 1945 he had encountered the real Russia. He wrote of his exile in 1955:

And I travelled on foot from village to village. ... I spent many nights in the huts of Russians and Mordovians. And many times feasted with them on their "altars." I observed things which it is unlikely that anyone from among the Muscovites will have seen. ${ }^{24}$

The Smena vekh ("Change of Landmarks") group was the earliest attempt to come to terms with the revolution, rather than simply to oppose it. They came into being after the publication of a volume of essays that was edited by N. Ustrialov in 1921 in Prague. They argued that the White movement was historically mistaken and that the Bolsheviks were the natural instruments of the national mission. The Smenovekhovtsy were seen as apologists for Bolshevism, and frightened the majority of émigrés. They were accused of being Soviet stooges, although Hilde Hardeman in her excellent analysis argues that this was not the case. They proposed that an acceptance of the revolution was necessary in order to prevent further struggle and destruction. Although they still had reservations about the Bolsheviks, they also saw "the October revolution as an expression of the Russian people's will and hence as a phenomenon which could not be disavowed." 25

In 1922, Lenin expelled many leading Russian philosophers, thinkers, and writers. ${ }^{26}$ For the most part, they did not wish to leave Russia; but their

23 Trest was a counter-intelligence operation in the USSR in the 1920s. Various émigrés became involved in it, believing that they could visit their homeland and aid opposition to the USSR, when most of them were in fact being monitored and provided with disinformation by the Soviet security services.

24 Letter of P. N. Savitskii to N. E. Andreyev 28/29 September, 1957 in N. E. Andreyev's archive. Translation mine.

25 Hilde Hardeman, Coming to Terms with the Soviet Regime: The "Changing Signposts" Movement among the Russian Émigrés in the Early 1920s (DeKalb: Northern Illinois University Press, 1994), 187.

26 See Lesley Chamberlain, The Philosophy Steamer: Lenin and the Exile of the Intelligentsia (London: Atlantic Books, 2006). 
views were inimical to the Bolsheviks, and Lenin had no use for a group who saw themselves as the conscience of society. He was afraid that executing them would produce too much international opprobrium, ${ }^{27}$ but he believed that exile would deprive them of their readership and diminish the impact of their ideas. Philosophers and theologians — such as Nikolai Berdiaev, Sergei Bulgakov, and others-attracted an extensive readership when their works became available in Russia once again. The focus of their ideas was the question of God and Man's relationship with the eternal, rather than a discussion of the impact of 1917. But it should be noted that a number of these thinkers contributed to Vekhi and continued the debate on these issues in Iz glubiny. ${ }^{28}$

1917 meant that an influential part of the intelligentsia had to leave Russia. It forced them to rethink many of their ideas and assumptions. They remained very focused on Russia, but the fundamental polarity was whether it should strive to overthrow the Bolshevik regime or to accept it. These arguments formed the basis of much émigré culture and were reflected in their publications. Many of the émigré political and military organizations proved to be ephemeral, and in the long term did not justify the attention which the Soviet security forces paid them. But it can be seen that there is a fundamental continuity between the pre-revolutionary debates and those which occurred among émigrés. In the course of the debates, they tried to clarify how they should relate to the USSR and what they valued in Russian culture. ${ }^{29}$ The research of such historians as Semion Lyandres ${ }^{30}$ has shown that there are still gaps in our understanding of 1917. To misquote Zhou Enlai, it is still too early to judge the impact of the Revolution, but it was a central concern of those who had to leave Russia after 1917.

\section{Bibliography}

Abraham, Richard. Alexander Kerensky: First Love of the Revolution. New York: Columbia University Press, 1987.

27 Stuart Finkel, On the Ideological Front: The Russian Intelligentsia and the Making of the Soviet Public Sphere (New Haven: Yale University Press, 2007), 166.

28 Iz glubiny: Sbornik statei o russkoi revoliutsii (Paris: YMCA Press, 1967 [1918]).

29 N. A. Omel'chenko, $V$ poiskakh Rossii: Obshchestvenno-politicheskaia mysl' russkogo zarubezh'ia o revoliutsii (St. Petersburg: Izdatel'stvo Russkogo khristianskogo gumanitarnogo instituta, 1996).

30 Semion Lyandres, The Fall of Tsarism: Untold Stories of the February 1917 Revolution (Oxford: Oxford University Press, 2013). 
Andreyev, Catherine. Vlasov and the Russian Liberation Movement: Soviet Reality and Émigré Theories. Cambridge: Cambridge University Press, 1986.

Bassin, Mark, Sergei Glebov, and Marlène Laruelle (eds), Between Europe and Asia: The Origin, Theories and Legacies of Russian Eurasianism. Pittsburgh: University of Pittsburgh Press, 2015. Butenko, Vasilii. “Partiinaia zhizn'. (Itogi 1930-31 goda).” Vestnik Krest'ianskoi Rossii (June-July 1931): 11-15.

Chamberlain, Lesley. The Philosophy Steamer: Lenin and the Exile of the Intelligentsia. London: Atlantic Books, 2006.

Finkel, Stuart. On the Ideological Front: The Russian Intelligentsia and the Making of the Soviet Public Sphere. New Haven: Yale University Press, 2007.

Glebov, Sergey. From Empire to Eurasia: Politics, Scholarship and Ideology in Russian Eurasianism (1920s-1930s). DeKalb: Northern Illinois University Press, 2017.

Hardeman, Hilde. Coming to Terms with the Soviet Regime: The "Changing Signposts" Movement among the Russian Émigrés in the Early 1920s. DeKalb: Northern Illinois University Press, 1994. Il'in, Ivan. Rodina, russkaia filosofiia, pravoslavnaia kul'tura, compiled with an introduction by E. S. Troitskii. Moscow: n.p., 1992.

Iskhod k Vostoku. Sofia: Rossiisko-bolgarskoe knigoizdatel'stvo, 1921.

Iz glubiny: Sbornik statei o russkoi revoliutsii. Paris: YMCA Press, 1967 [1918].

Katkov, George. Russia 1917: The February Revolution. London: Longman, 1967. . The Kornilov Affair. London: Longman, 1980.

Laruelle, Marlène. Russian Eurasianism: An Ideology of Empire, translated by M. Gabowitsch. Baltimore: John Hopkins University Press, 2008

Lyandres, Semion. The Fall of Tsarism: Untold Stories of the February 1917 Revolution. Oxford: Oxford University Press, 2013.

Miliukov, Pavel. "Intelligentsiia i istoricheskaia traditsiia." Intelligentsiia v Rossii: Sbornik statei, 89-192. St Petersburg: Zemlia, 1910.

. Istoriia vtoroi russkoi revoliutsii. Sofia: Rossiisko bolgarskoe knigoizdatel'stvo, 1921-23. . Vospominaniia (1859-1917). New York: Izdatel'stvo imeni Chekhova, 1955.

Omel'chenko, N. A. V poiskakh Rossii: Obshchestvenno-politicheskaia mysl' russkogo zarubezh'ia o revoliutsii. St Petersburg: Izdatel'stvo Russkogo Khristianskogo gumanitarnogo instituta, 1996.

Scanlan, James P., ed. Russian Thought after Communism: The Recovery of a Philosophical Heritage. Armonk: M. E. Sharpe, 1994.

Smena vekh. Prague: Nasha rech', 1921.

Solzhenitsyn, Aleksandr I. Arkhipelag GULag, 1918-1956, vols 1-2. Paris: YMCA-Press, 1973.

Stephan, John J. The Russian Fascists: Tragedy and Farce in Exile 1925-1945. London: Hamish Hamilton, 1978.

Stockdale, Melissa K. Paul Miliukov and the Quest for a Liberal Russia. Ithaca: Cornell University Press, 1996.

Tikhanov, Galin. "Continuities in the Soviet Period." In A History of Russian Thought, edited by W. Leatherbarrow and D. Offord, 311-339. Cambridge: Cambridge University Press, 2010. Tromly, Benjamin. “The Making of a Myth.” Journal of Cold War Studies 18, no. 1 (2016): 80-111. Vekhi: Sbornik statei o russkoi intelligentsii. Moscow: I. N. Kushnerev, 1909. 